\title{
ECONOMIC EFFICIENCY OF THE LAND RESOURCE MANAGEMENT AND AGRICULTURAL LAND-USE BY AGRICULTURAL PRODUCERS
}

\author{
Ruslana Sodoma ${ }^{1}$, Tetiana Shmatkovska ${ }^{2}$, Mykola Dziamulych ${ }^{3}$, Nataliia Vavdiiuk ${ }^{4}$, Nataliia \\ Kutsai ${ }^{5}$, Vadym Polishchuk
}

${ }^{1}$ PhD, Associate Professor, Lviv State University of Life Safety, Volodymyra Velykogo st., 1, Dublyany Zhovkivsky district, Lviv region, Ukraine, E-mail address: sodomaruslana@gmail.com

${ }^{2}$ PhD, Associate Professor, Lesya Ukrainka Volyn National University, 28 Vynnychenko Street, Building $7(G), 43025$, Lutsk, Volyn region, Ukraine, E-mail address: shmatkovska2016@gmail.com, 7tresure@ukr.net, shmatkovska.tetyana@vnu.edu.ua

${ }^{3}$ PhD, Associate Professor, Lutsk National Technical University, 75 Lvivska str., 43018, Lutsk, Volyn region, Ukraine, E-mail address: m.dziamulych@lntu.edu.ua

${ }^{4}$ Dr.Sc., Professor, Lutsk National Technical University, 75 Lvivska str., 43018, Lutsk, Volyn region, Ukraine, E-mail: n.vavdiyuk@lntu.edu.ua

${ }^{5}$ PhD, Associate Professor, Lutsk National Technical University, 75 Lvivska str., 43018, Lutsk, Volyn region, Ukraine, E-mail address: nataliakutsai@gmail.com

${ }^{6}$ PhD, Associate Professor, Lutsk National Technical University, 75 Lvivska str., 43018, Lutsk, Volyn region, Ukraine, E-mail address: vadym.polischuk2@gmail.com

Received 0503 2021; Accepted 14042021

\begin{abstract}
To assess the effectiveness of the management of land resources for agricultural enterprises suggested factors affecting the market for agricultural products, which integrates a system of environmental, economic and social indicators in this area. The paper highlights main theoretical aspects of the land resource management of the agricultural enterprises. The essence of land resource management is shown based on the definition of the objects of management, which are land resources of agricultural enterprises, subjects of management, which are landowners and employees of such agricultural enterprises, and objective of management, which is providing and maintaining the efficiency of land resources usage as a key factor of agricultural production.

The land market and its structure are presented in detail. The characteristic structure of land resources leading European countries. Described prospects management of land resources of agricultural enterprises. A complete analysis of mortgage lending secured by agricultural lands has been carried out. A decrease in the number of agricultural enterprises, which is mostly connected with imperfections of land governance, formed in the state, has been identified. Relationships between strengths and weaknesses of agricultural enterprises, opportunities, and threats of efficient land use have been identified. Scenarios of economic development have been considered, which should be taken into account while developing a strategy.
\end{abstract}

Keywords: agricultural management, agricultural producers, land use strategic goals, economic efficiency. JEL Codes: Q10, Q12, Q15.

\section{Introduction}

Economic instability in the country, increased competition, and saturation of the domestic market imported agricultural products, changing climate conditions that increase the risk of crop failure, lack of financial resources to ensure quality cultivation and opportunities for its recovery, lack of qualified personnel - a major obstacle to the organization effective land use domestic agricultural enterprises.

Copyright (C) 2021 Author(s), published by Vytautas Magnus University. This is an open access article distributed under the terms of the Creative Commons Attribution Non-Commercial 4.0 (CC BY-NC 4.0) license, which permits unrestricted use, distribution, and reproduction in any medium provided the original author and source are credited. The material cannot be used for commercial purposes. 
Land relations in the agricultural sector should focus on their effective use in the long term.

In modern terms the share of those wishing to transfer land to rent because of the lack of opportunities for doing her own agricultural production.

The system of land administration affects the development of legal security (which is the main requirement for the investors), the access to the credit (the mortgage), spatial planning (to support economic and ecological development) and the efficient and effective land taxation (Zeeuw and Salzmann, 2011).

The main problem in the use of agricultural land in Ukraine is viewed as a discrepancy between ownership and use (Popov et al., 2019). An excessive lease of agricultural land by agroholdings (big agricultural enterprises) made it possible to form a good structure of land use (fields). Based on the analysis of scientific sources revealed that determining the efficiency of land use of agricultural enterprises should take into account not only the economic effect of management but the level of satisfaction of people's needs in food, preservation and restoration of soil fertility, yield owners of land and farmworkers.

Land, as a basis of living space for human societies, has always played a special role in history. Besides, the land is the main source of providing humanity with food necessities and therefore a key factor in maintaining social stability. Thus, it is possible to conclude, that land is a unique strategic asset, inseparable from history, present and future of societies, which inhabited particular territories at different times. Therefore, it isn't correct to consider land as an ordinary commodity or raw material. At the same time land, and agricultural land in particular, as the object of human economic activity, has its own economic aspects. This raises the questions about the settlement of legal issues, connected to land use and ownership. Intensive agricultural land use leads to a decrease in soil fertility through compaction, in particular of black soil.
The relevance of the selected study is due to environmental, economic and social problems that exist in Ukraine regarding the adoption of the goal of sustainable development by 2030 , in particular, the rational use of landresource potential, and in particular agricultural land.

\section{Literature review}

The problem of land administration in the scientific literature paid much attention in research O. Atamaniuk and $\mathrm{H}$. Hreshchuk (2017), H. Hreshchuk (2019), G. Pasakarnis (2013), R. Stupen et al. (2019), A. Tretiak et al. (2019), etc. However, the problem in the agricultural domain so far is not resolved and requires further in-depth scientific research in this area. A necessary condition for effective development of land relations, strategies and evaluation of effective land use of agricultural enterprises is to develop effective land management tools.

Given the value of the results should indicate that some aspects of the outlined topics require further study. The research scientists $\mathrm{O}$. Atamaniuk and $\mathrm{H}$. Hreshchuk have theoretical and practical importance for the agricultural sector because it allowed us to estimate the longterm development of land relations (Atamaniuk and Hreshchuk, 2017). However, rangeland resources were not fully covered.

\section{Methodology}

The theoretical and methodological basis of the research is the basic provisions of modern economic theory, the work of leading domestic and foreign scientists on the issues of land use. In the article, all materials are worked out by means of a complex of methods of scientific research, in particular the direct description of the studied phenomenon, processing of statistical information by means of economic methods of research, representation of the received results by means of a graphic method. 


\section{Sciendo}

Management Theory and Studies for Rural Business and Infrastructure Development

eISSN 2345-0355. 2021. Vol. 43. No. 4: 524-535

Article DOI: https://doi.org/10.15544/mts.2021.47

Research uses common scientific methods, namely: a monographic analysis, which is a study of scientific publications on the effective use of land resources and, in particular, rational use of agricultural lands; grouping - for grouping forms

\section{Results and discussions}

Land reform and the ongoing process of improving land relations, especially in the field of agriculture in Ukraine, have shown a number of problems related to the use of agricultural land resources. At the present stage of economic management, the efficient use of land resources of agricultural enterprises is one of the most important problems of the agrarian policy of our country. This is due to the dominance of not very effective agricultural lease relations, which has a significant impact on the performance of farms in general.

At the present stage, the role of the state in the land market in Ukraine is increasing. First of all, this is due to the need of forming a wide legal field and adoption of a number of legislations. Besides, the need for state regulation is explained by:

- the existence of a shadow market in which land transactions are concluded underground and remain uncontrolled;

- the need to develop economic programs for the development of the agricultural sector in order to provide financial and organizational support to economic subjects;

- the need to ensure proper protection of land through rational use, conservation of land and improvement of their properties in the process of use (in most developed countries of the world there are sets of environmental and technological requirements, standards and restrictions for landowners to improve the ecological condition of agricultural land, termination of degradation processes, improvement of soil quality);

- the need to develop the infrastructure of the land market;

- the need of strict control over compliance with all landowners and land users of the provisions of the Land Code and other legal acts on land and to prevent speculation with the land, the need to control the transfer of land and sells on a competitive basis;

- strengthening of the state control over the process of parcellation of productive lands, which has become uncontrolled in Ukraine.

Table 1 shows an estimation of providing of the system of land resources administration in Ukraine with a description of the condition of each sector of land administration.

Table 1. Evaluation of institutional support for the land administration system in Ukraine

\begin{tabular}{lcc}
\hline \multicolumn{1}{c}{ Sector of land administration } & Current condition & $\begin{array}{c}\text { Rating, } \\
\boldsymbol{\%}\end{array}$ \\
\hline Land policy in the field of land relations & Fair & 49 \\
\hline including lease relationship & Good & 34 \\
\hline Land policy in the field of use and conservation & Fair & 43 \\
\hline including economic promotion of rational land use and conservation & Very poor & 23 \\
\hline Mechanisms of implementation of land policy & Poor & 27 \\
\hline including land conservation policy & Very poor & 20 \\
\hline Regulation and administration of land relations & Poor & 37 \\
\hline including the protection of land rights & Fair & 20 \\
\hline Regulation and administration of the organization of land use and protection & Poor & 33 \\
\hline including economic incentives for land use & Very poor \\
\hline Source: Own results. & 25 \\
\hline
\end{tabular}


Results have shown that the current condition of lands in Ukraine requires improvement of law support for monitoring of the state of lands. The monitoring of agricultural land should be carried out twice a year (on the local level). The first time before sowing, the second - after the harvest. The results of such monitoring are characteristics of changes in soil properties, which makes it possible to assess the degree of agricultural impact on their condition.

In fig. 1 shows a cartogram based on the results of grouping the regions of Ukraine by the area of land on which in 2019 operations in the field of market turnover took place.
According to the results of the analysis of the cartogram developed by authors (Fig. 1 ), it can be stated that the activity of the agricultural land market functioning in Ukraine is determined by the frequency of their market turnover. In particular, the largest area of land plots on which market operations took place in 2019 can be traced in the Vinnytsia, Poltava, Cherkasy, Kirovohrad regions of Ukraine. The smallest area of land plots on which market operations took place in 2019 is typical for the Rivne and Zakarpattia regions of Ukraine. Thus, we summarize that the results of our analysis revealed that in the border western regions of Ukraine the studied indicators are the lowest.

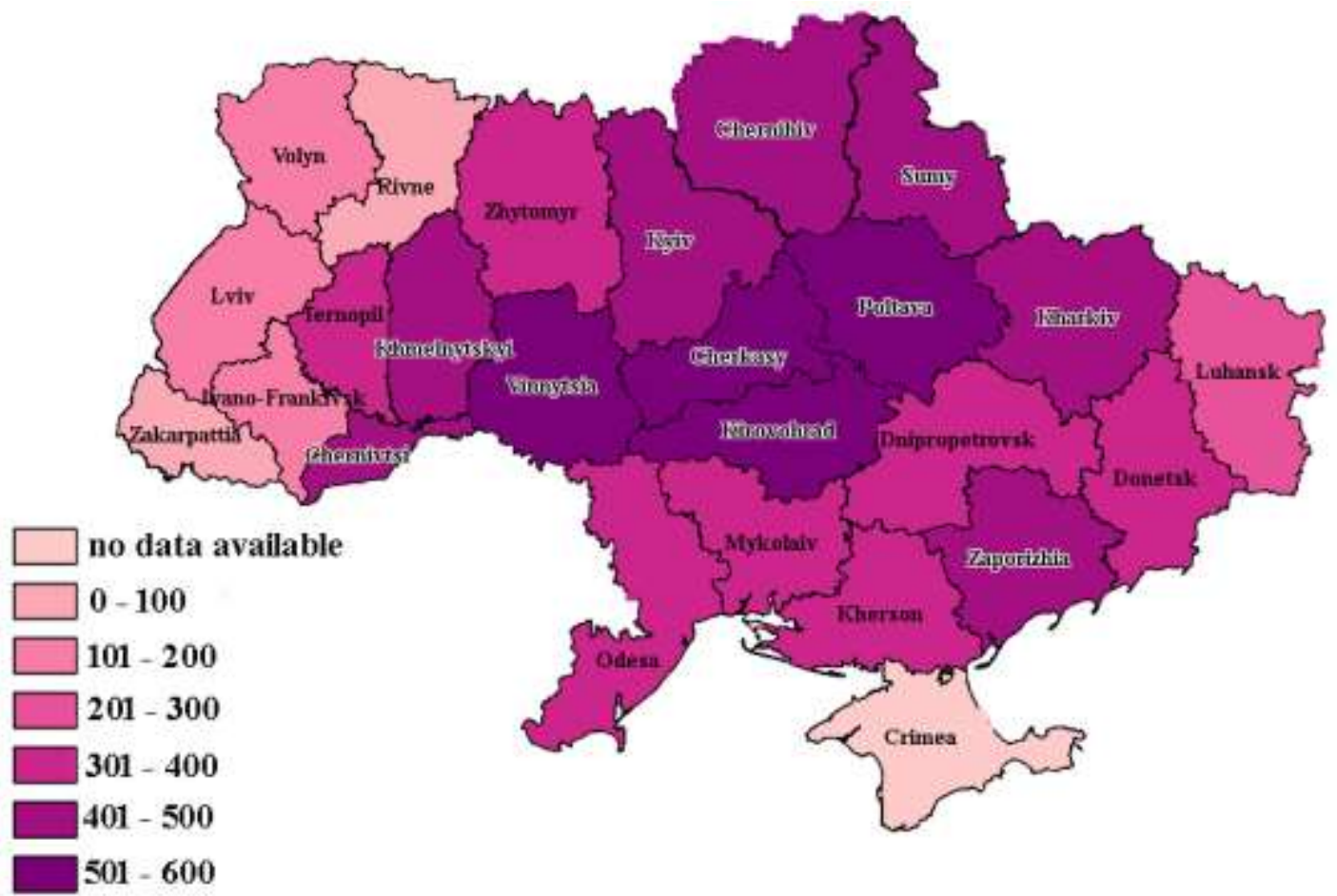

Figure 1. Cartogram of the grouping of the regions of Ukraine by the area of land plots on which market turnover operations took place in 2019, ha

*Note: Data on the Autonomous Republic of Crimea is not available due to the occupation of this territory. Own design based on the sources: (Department of Statistics in Lviv Region, 2020).

Multifunctional land use defines land management and land use as one of the main factors for the balanced development of rural and urban territories and the country as a whole, which should aim to ensure costeffective and environmentally friendly land use to achieve public welfare. Analyzing the specificity of land as an aggregate natural resource, it should be noted that it is considered in the following main ways (A. Tretiak et al., 2017):

- the land is the territory of the country, the main state-forming component (national security);

- the land is a universal spatial basis that is constantly supported by a certain correlation of land categories and land use types (spatial security) (Sodoma et al., 2018); 


\section{sciendo}

Management Theory and Studies for Rural Business and Infrastructure Development

eISSN 2345-0355. 2021. Vol. 43. No. 4: 524-535

Article DOI: https://doi.org/10.15544/mts.2021.47

- the land is the main means of production in agriculture and forestry (food security) (Land Code of Ukraine, 2001);

- the land is a major component of nature (environmental safety);

- the land is a stockpot of water, mineral, forest, recreational and other resources (economic security).

The basis of balanced use of land resources is the choice of the most effective option for their use, in terms of solving certain environmental and economic priorities (Hreshchuk, 2019).

Management of land resources is carried out at the national, regional and within farms. The scheme management of land resources of agricultural enterprises is shown in Figure 2.
The main strategic directions of improving the efficiency of land use at the micro-level are: maintaining and improving soil fertility; introduction of new cultivation technologies; maximizing profit; improve productivity and increase agricultural production; meet the interests of all participants in land relations. At the territorial level is advisable first to provide support for the priority areas of the territory of agricultural production, sustainable land use, and environmental friendliness. At the national level is necessary to improve the institutional framework and environmental policies on agricultural production systems, establish effective programs to support its investment support.

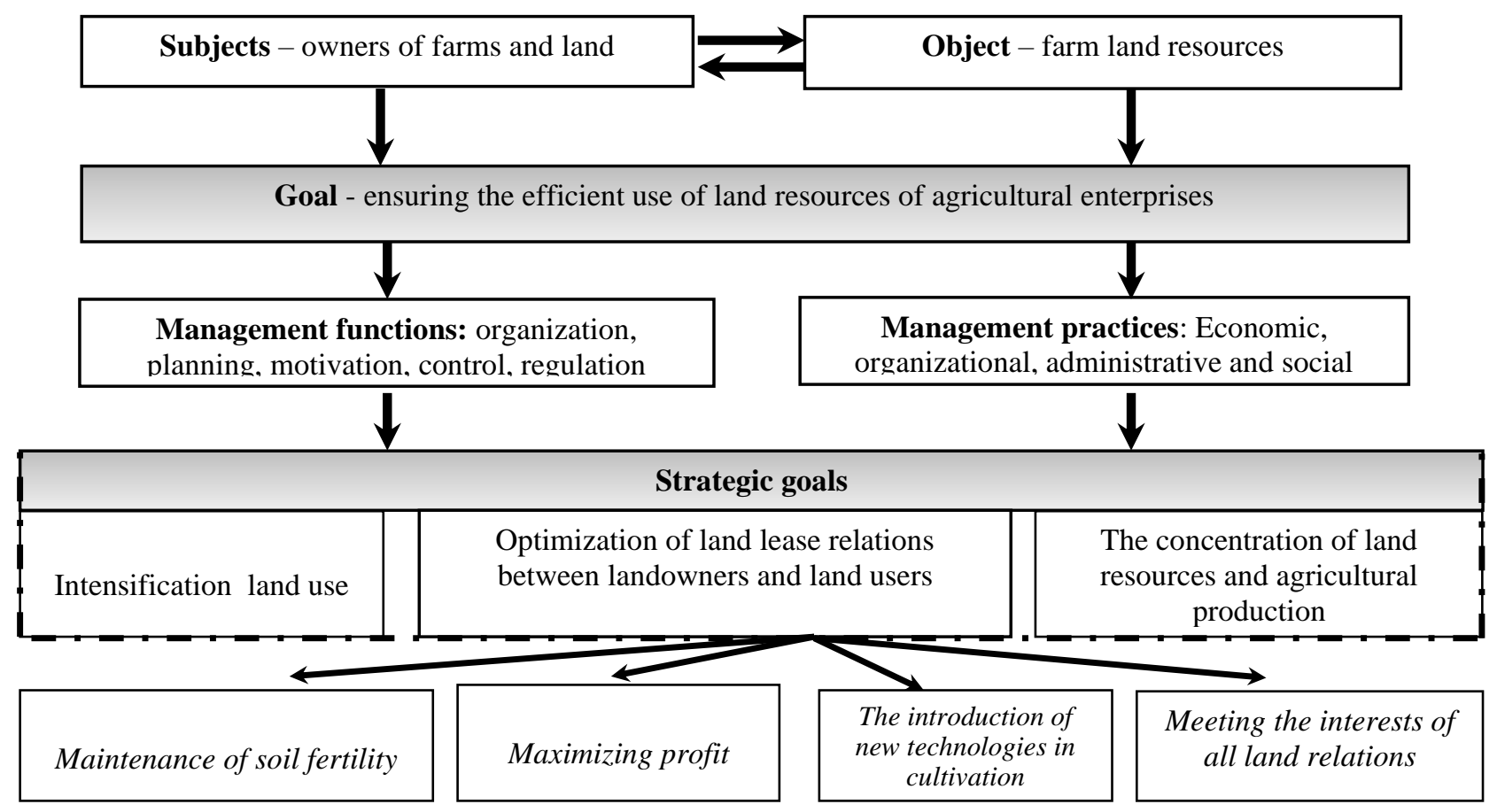

Figure 2. Scheme of the management of land resources of the agricultural enterprises *Source: Own design.

The cartogram of the grouping of districts of the Lviv region of Ukraine by the area of agricultural lands in 2019 is given in Fig. 3. 


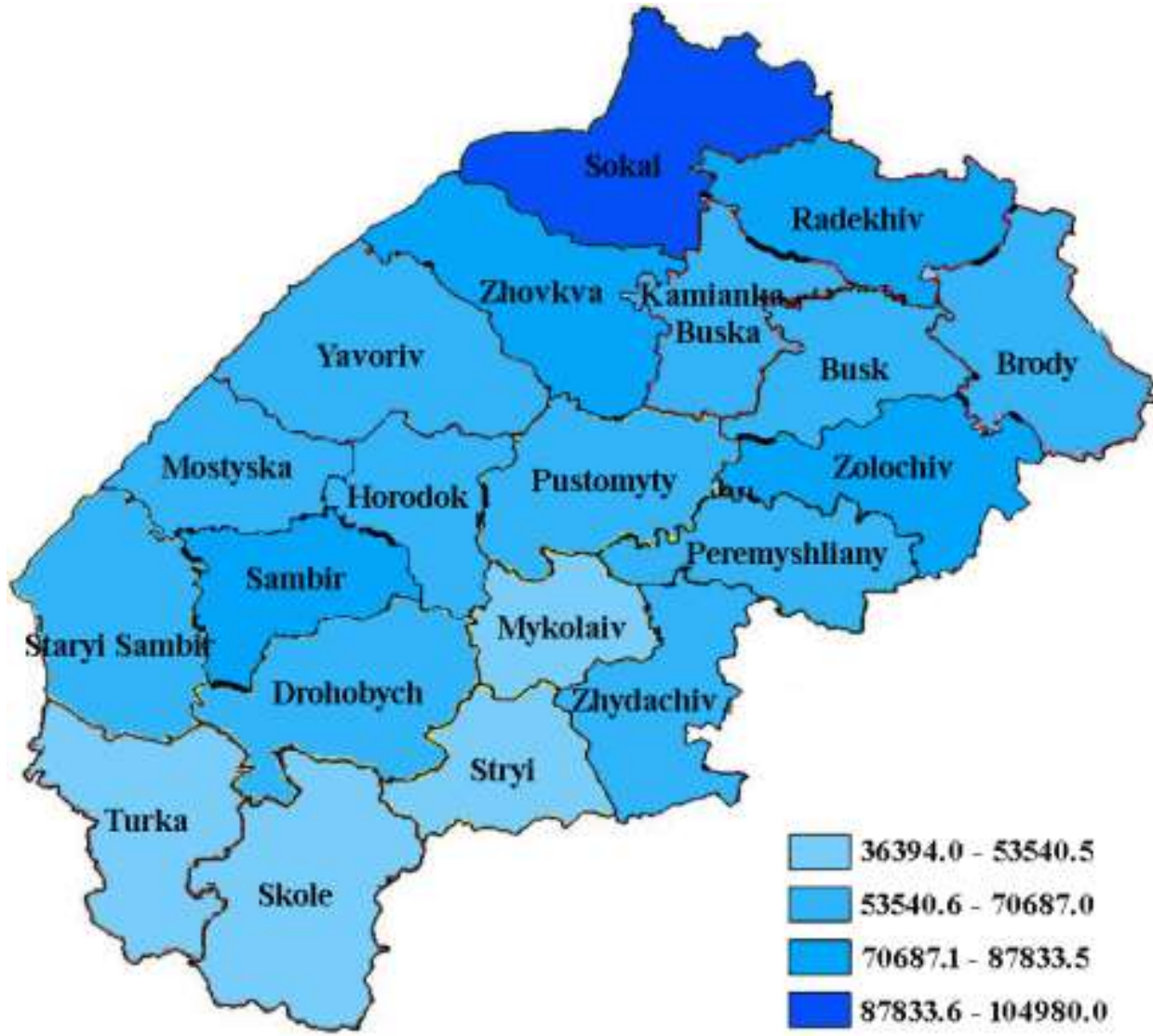

Figure 3. Cartogram grouping of districts of the Lviv region of Ukraine by area of agricultural land in 2019, ha

Own design based on the sources: (Department of Statistics in Lviv Region, 2020).

According to the results of the analysis of the grouping, we found that the largest area of agricultural land as of 2019 is available in the Sokal district of Lviv region of Ukraine. In addition, the area of agricultural land is also high in Zhovkva, Zolochiv, Sambir, and Radekhiv districts of the Lviv region of Ukraine. The lowest indicators on the size of agricultural land in 2019 are typical for mountainous areas of the Lviv region of Ukraine, included in the first group, namely Turkiv, Skoliv, Stryi, Mykolaiv districts of Lviv region.

We believe that the results of the analysis of the grouping of districts of the Lviv region of Ukraine by area of agricultural land will provide an opportunity to justify our trends and features of economic efficiency of land use in the studied region of Ukraine.

In our opinion, it is advisable to structure the factors within each study group and detail them in order to determine the impact on agricultural land use, the ability to achieve and increase the efficiency of such use.

In order to study the effect of environmental factors on the activities of agricultural enterprises and their efficient use of land resources held a questionnaire survey of a number of enterprises in the agricultural sector. Respondents depicted in Fig. 4. 


\section{Sciendo}

Management Theory and Studies for Rural Business and Infrastructure Development

eISSN 2345-0355. 2021. Vol. 43. No. 4: 524-535

Article DOI: https://doi.org/10.15544/mts.2021.47
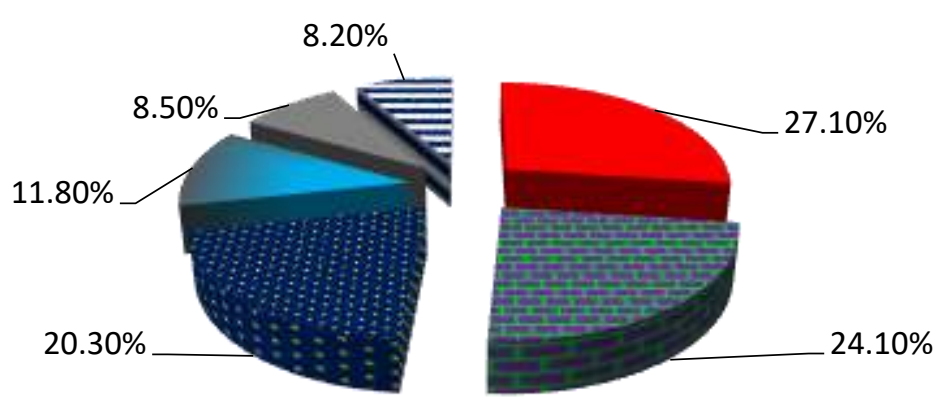

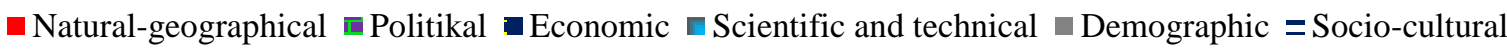
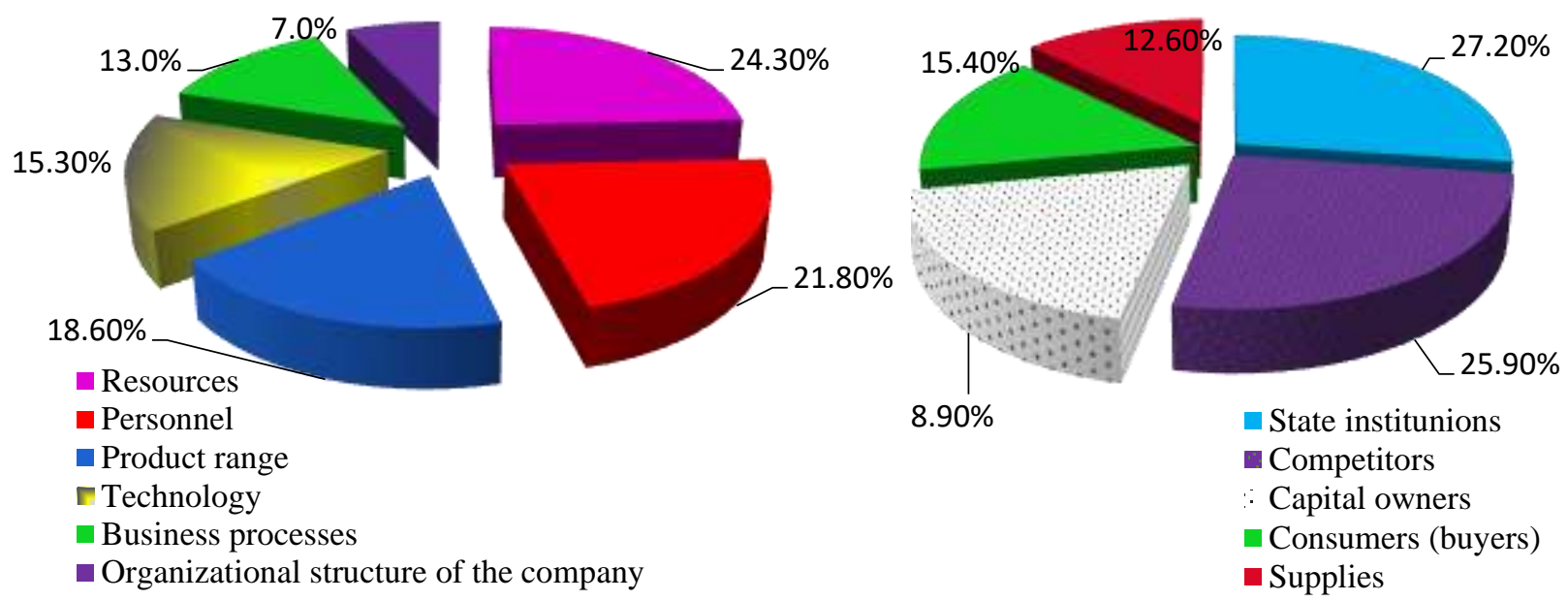

Figure 4. The results of a questionnaire survey (questionnaire) of managers of the agricultural enterprises regarding the factors influencing the use of land resources in Ukraine (factors of the internal environment, macro-environmental and microenvironmental factors)

*Source: Own design based on the sources: (Doing Agribusiness in Ukraine 2020, 2020; Ministry of Agrarian Policy and Food of Ukraine, 2020; Shaxson, 2008).

It is established that the greatest influence on the use of land resources of enterprises is made by natural-geographical $(27.1 \%)$ and political $(24.1 \%)$ factors, further, in the order of decline of influence - economic $(20.3 \%)$, scientific and technical (11.8\%), demographic $(8.5 \%)$ and socio-cultural (8.2\%). Among the factors, micro-level of influence divided as follows: state institutions (27.2\%), competitors (25.9\%), capital owners (18.9\%), consumers (buyers) (15.4\%), suppliers $(12.6 \%)$. Factors of the internal environment, according to respondents, affecting land use of agricultural enterprises as resources $-24.3 \%$ personnel $-21.8 \%$ product range $-18.6 \%$, technology $-15.3 \%$, business processes - $13.0 \%$ and the organizational structure of the company $3.0 \%$.

According to the financial and economic reporting, we conduct correlationregression analysis for a sample set of agricultural enterprises of Lviv region of Ukraine. To construct the regression equation, the value of commodity output per 100 ha of agricultural land (Y) was selected as the dependent variable, and the following indicators were selected as independent variables: area of agricultural land $\left(\mathrm{X}_{1}\right)$; costs per 1 ha of agricultural land $\left(\mathrm{X}_{2}\right)$; rate of return $\left(\mathrm{X}_{3}\right)$ (Table 2). 
According to the data in Table 1, it can be argued that the relationship between commodity values per 100 ha of agricultural land and production costs per 1 ha of agricultural land is very strong (pair correlation coefficient is 0.981 ), and between commodity production and the area weak inverted (correlation coefficient -0,192), between commodity products and the rate of return - also inverted, but moderate enough (even correlation coefficient is $-0,689$ ). The corresponding regression equation is:

$$
\mathrm{Y}=-918.31+0.27 X_{1}+142.64 X_{2}+21.51 X_{3}
$$

Table 2. Correlation matrix of relationships formation of individual indicators of economic activity of agricultural enterprises of Lviv region of Ukraine for 2019

\begin{tabular}{ccccc}
\hline Indicator & $\begin{array}{c}\text { Commodity } \\
\text { production per } \\
\mathbf{1 0 0} \text { ha of } \\
\text { agricultural land }\end{array}$ & $\begin{array}{c}\text { Area of } \\
\text { agricultural land }\end{array}$ & $\begin{array}{c}\text { Production costs per } \\
\mathbf{1} \text { ha of agricultural } \\
\text { land }\end{array}$ & $\begin{array}{c}\text { The rate of } \\
\text { return }\end{array}$ \\
\hline $\begin{array}{c}\text { Commodity production per 100 ha of } \\
\text { agricultural land }\end{array}$ & 1 & $\mathrm{X}$ & $\mathrm{X}$ & $\mathrm{X}$ \\
\hline $\begin{array}{c}\text { Area of agricultural land } \\
\text { Production costs per 1 ha of } \\
\text { agricultural land }\end{array}$ & -0.192 & 1 & $\mathrm{X}$ & $\mathrm{X}$ \\
\hline The rate of return & 0.981 & -0.219 & 1 & $\mathrm{X}$ \\
\hline
\end{tabular}

*Source: Own research and calculations.

The coefficient of determination is quite high (0.976). Therefore, the $97 \%$ variation in commodity output per 100 ha of agricultural land can be explained by a change in the model factors selected, and the remaining 3\% (100-97) is the influence of factors not included in the model. It should be noted that the values of the regression coefficients have a very important economic interpretation and can be used to calculate the predicted values of the volume of commodity products.

In Ukraine, after the moratorium on the sale and purchase of agricultural land has ceased, it is advisable to introduce a legislative mechanism of increased responsibility for land use. It is important to anticipate the intended use of agricultural land without the right to sell the land within five years from the date of acquiring the ownership of the land (while introducing an exemption from land tax for a period of five years), as well as to introduce a high level of taxation on land sales income for short-term use and a regressive tax scale depending on tenure (to encourage long-term land use).

Foreign land management experience should be taken into account when addressing problems of improving land use in Ukraine. Particular attention should be paid to the organization of regular land monitoring as a basis for effective land management (Table 3).

Table 3. Comparative characteristics of land use status in European countries and Ukraine

\begin{tabular}{ccccc}
\hline Characteristic & Ukraine & $\mathbf{\%}$ & EU countries & \% \\
\hline Land area, million hectares & 60.4 & 100 & 437.4 & 100 \\
\hline Area of black soil, million hectares & 28 & 46.36 & 18 & 4.12 \\
\hline Area of agricultural land, million hectares & 42.7 & 70.70 & 177.7 & 40.63 \\
\hline Area of agricultural land per capita, ha/person & 0.7 & 1.16 & 0.4 & 0.09 \\
\hline Area of leased agricultural land, \% & 41.4 & 68.54 & 94.2 & 21.54 \\
\hline Investment price, thousand USD / ha & 1 & 1.66 & 5.5 & 1.26 \\
\hline
\end{tabular}

*Source: Own design based on the sources: (A. Tretiak et al., 2017). 


\section{S sciendo}

Management Theory and Studies for Rural Business and Infrastructure Development

eISSN 2345-0355. 2021. Vol. 43. No. 4: 524-535

Article DOI: https://doi.org/10.15544/mts.2021.47

This table shows that in spite of the considerable land area in the EU countries, in percentage terms the area of black soil in Ukraine is much higher and $70 \%$ occupy the area of agricultural land (the largest share is occupied by arable land).

The argument in favor of securing land as a source of financial support for agricultural economic growth is that in the world, loans secured by land make up $95 \%$ of farmers' investment resources, and only $5 \%$ is money from the sale of land. According to experts, the use of a mortgage will allow agricultural companies to increase the volume of received loans by 6-9 times, to extend loans by 7-11 times - up to 35 years with significantly lower interest rates on loans (up to 9\%) and substantially secure (up to $100 \%$ ) lending.

There are about 1.7 million hectares of land, which is $4 \%$ of all agricultural land.

Experts estimate that if only $10 \%$ of the agricultural land is included in the mortgage lending system, with a loan level of $60 \%$ of the value of the collateral, this would increase the potential of the agricultural sector by $\$ 2.4$ billion (Yakubiv et al., 2019).
Accordingly, in the process of land use development, the first group of state land interests (social) focuses on the size of property for different social groups and land use forms. An important task for Ukraine is the transfer of land policy into a group of environmental and social interests and improving the well-being of rural and urban populations in Ukraine.

The purpose of land management regulation is the establishment of obligatory qualitative and quantitative indicators aimed at ensuring the sustainable use, protection and reproduction of land, as well as ensuring environmental safety in land relations (Pasakarnis, 2013).

First of all, we must consider all external and internal factors affecting the development of the market of agricultural lands in order to fulfill our task. In our opinion, it is appropriate to systematize these factors into four large groups: environmental, economic, social and legal. Factors that influence the development of agricultural lands market in Ukraine (Table 4).

\section{Table 4. Assessment of Ukrainian land use trends according to economic interests, social interests, environmental interests, 2019

\begin{tabular}{cccccccc}
\hline Ownership & $\begin{array}{c}\text { Number of land } \\
\text { owners and land } \\
\text { users }\end{array}$ & $\begin{array}{c}\text { Total area } \\
\text { of land, ha }\end{array}$ & $\begin{array}{c}\text { Agricultural } \\
\text { land, ha }\end{array}$ & $\begin{array}{c}\text { Forests and } \\
\text { other wooded } \\
\text { areas, ha }\end{array}$ & $\begin{array}{c}\text { Land under } \\
\text { buildings, ha }\end{array}$ & $\begin{array}{c}\text { Water, } \\
\text { ha }\end{array}$ & $\begin{array}{c}\text { Other, } \\
\text { ha }\end{array}$ \\
\hline
\end{tabular}

\begin{tabular}{|c|c|c|c|c|c|c|c|}
\hline \multicolumn{8}{|c|}{ Economic interests } \\
\hline Citizens & 2932217 & 9994.6 & 10309.2 & 3.2 & 24.9 & 89.7 & 9.9 \\
\hline Legal entities & 161457 & 45206.7 & 48436.1 & 1464.9 & 988.7 & 814.8 & 997.1 \\
\hline Total & 3093674 & 55201.3 & 58745.3 & 1467.9 & 1012.79 & 904.5 & 45080.1 \\
\hline \multicolumn{8}{|c|}{ Social interests } \\
\hline Citizens & 23376584 & 6857.2 & 6425.2 & 2.9 & 524.8 & 0.4 & 5.1 \\
\hline Legal entities & 192014 & 7002.2 & 2928.6 & 933.8 & 1128.5 & 1472.2 & 539.1 \\
\hline Total & 23568598 & 13859.4 & 9353.8 & 45009.8 & 1653.3 & 1472.6 & 44374.1 \\
\hline \multicolumn{8}{|c|}{ Environmental interests } \\
\hline Citizens & 48132 & 4.7 & 2.5 & 0.0 & 2.6 & 0.0 & 0.0 \\
\hline Legal entities & 13533.0 & 11173.8 & 959.2 & 9547.7 & 64.9 & 318.2 & 614.9 \\
\hline Total & 61665 & 55189.8 & 44912.2 & 9547.7 & 44048.9 & 318.2 & 614.9 \\
\hline
\end{tabular}

Own design based on the sources: (Sodoma et al., 2018).

Ecological factors (This group includes all factors that have an ecological component. The composition and type of soil, the level of contamination and the environmental policy of the land user influence the level of demand and supply according to a particular land plot); 
Economic factors (We consider that it is appropriate one can include those factors that directly affect the price of the land plot as one of the most important factors of influence on demand and supply to this group);

Social factors (This group includes all factors that are in some ways connected with the social sphere, which supports economic activity with two most important components: labor resources and consumers of the final product (R. Stupen et al., 2019).

Economic interests in the field of distribution and redistribution of land are aimed at the structure of land ownership in the composition, combined with the proposal, which forms its economic form. At the same time, the interests of society are focused not only on maintaining under state control the necessary part of land resources to solve the general problem of land development and territorial resources, but also on the fact that this vital factor usually belongs to private owners, because they can skillfully and most efficiently use land resources. In addition, environmental interests are focused on the parameters of the functional and economic structure of the land fund, namely the size, proportion, and priorities of its distribution, types, and categories (hayfields, pastures, areas under construction, forests, shrubs, swamps, etc.), exploitation intensity and anthropogenic effects.

The process of managing and using land resources. Comparative evaluation of Land Resources of Ukraine and foreign countries is shown in Table 5.

Table 5. Comparative evaluation of Land Resources of Ukraine and foreign countries in 2019

\begin{tabular}{c|l|c|c}
\hline $\begin{array}{c}\text { The structure of land } \\
\text { resources }\end{array}$ & \multicolumn{1}{|c|}{ Categories of land } & Ukraine, \% & $\begin{array}{c}\text { USA, France, Sweden, } \\
\text { Germany, \% }\end{array}$ \\
\hline \multirow{4}{*}{$\begin{array}{c}\text { The economic } \\
\text { component }\end{array}$} & Agricultural lands & 70 & 55 \\
\cline { 2 - 4 } & plowed land & 54 & 33 \\
\cline { 2 - 4 } & Forestry purposes & 17 & 30 \\
\cline { 2 - 4 } & reforestation area & 0.7 & 15 \\
\cline { 2 - 4 } & Water Facility & 4 & 1 \\
\cline { 2 - 4 } & Industry and other lands & 2 & 15 \\
\hline Ecological component & A nature reserve and other purposes & 2 & 3 \\
\hline \multirow{4}{*}{ The social component } & Housing and other buildings & 0.3 & 5 \\
\cline { 2 - 4 } & Health purpose & 0.3 & 3 \\
\cline { 2 - 4 } & Historical and cultural & 0.6 & \\
\cline { 2 - 4 } & Reserve land & 5 & 3 \\
\hline
\end{tabular}

*Own design based on the sources: (Sodoma et al., 2018).

From this table shows that in our country there are problems in the distribution of land, affecting their effective use. The issue of state regulation of the land market in the aspect of environmental regulation cannot be overlooked. In general terms, world experience submits three possible mechanisms for achieving economic goals, including environmental and economic goals.

Land interests that arise in society can be divided into three groups: Social - to meet the physical, psychological, intellectual and other needs, both rural and urban;

Economic - regarding the commodity and monetary parameters of land ownership;
Ecological - refers to the effective development of the land resource and the nature of the property.

In the presence of high debt dependence of the economy and hostilities in the country, the implementation of unfavorable agrarian reforms for agricultural producers must independently, without much support of the state try to increase production volumes, enter foreign markets, ensure the efficiency of land use.

Because only with the unity of all three groups of social, economic and environmental interests that we can achieve the social wellbeing of rural and urban populations and overcoming threats, especially environmental ones, in nature. 


\section{Sciendo}

Management Theory and Studies for Rural Business and Infrastructure Development

eISSN 2345-0355. 2021. Vol. 43. No. 4: 524-535

Article DOI: https://doi.org/10.15544/mts.2021.47

The lease of hundreds, and in some cases thousands, of land parcels, requires large financial (about USD 11.20 per one hectare) and time costs (from 3 months or more) on registration of the lease rights. The availability of the unofficial payments leads to an increase in the registration costs of lease rights by $50 \%$ (Shmatkovska et al., 2020).

The implementation of the agricultural land market model will have the following positive socio-economic consequences:

- the full realization of the right of private ownership of agricultural land by the citizens of Ukraine, when the landowner will independently choose one of three directions: production of agricultural products on their own land using both their own capital and obtaining loans secured by the land; transfer of land for rent to another agricultural producer for rent; sale of land for the purpose of obtaining money;

- increasing the investment attractiveness of the agricultural sector, in particular through the development of mortgage loans secured by agricultural land;

- establishing the objective market value of agricultural land in the course of their economic circulation and increasing the capitalization of land;

- rational redistribution of agricultural lands and optimization of their use;

- increasing the amount of rent for agricultural land, which will become one of the main sources of replenishment of local budgets;

- creation of middle-class farmers;

- a guaranteed minimum level of employment of the rural population in the agricultural sector;

- creating a strong fiscal framework for the activity of local communities sufficient to support the socio-economic development of rural areas;

- improving the demographic situation in rural areas and revitalizing the Ukrainian countryside;

- increase of the level of motivation of work through the combination in the person of the citizen of Ukraine the landowner and the producer of agricultural products;

- increasing the efficiency of the use of the land's natural resource potential and ensuring the strategic food security of the state;

- full legalization of land ownership and land use, elimination of «shadow» schemes of agricultural land transfer, prevention of raider schemes of agricultural land capture;

operations;

- ensuring transparency of land

- preventing the purchase of agricultural land by «figurehead».

\section{Conclusions}

The intensification of agricultural production aimed at more efficient use of land and other resources through additional investment, the use of advanced technology, modern forms of production and labor.

The main role of inefficient land-use policy plays a land formed within the agricultural enterprise. More efficient use of land resources due to the achievement of strategic objectives, which are: optimization of land lease relations between landowners and land users, concentration and intensification of agricultural production. Achieving these goals is possible for the implementation of the strategic imperatives of environmental, economic and social issues. Specifically, the main strategic imperatives improve the efficiency of land use of agricultural enterprises are: ensuring soil fertility; introduction of new cultivation technologies; maximizing profit; improving productivity and increasing the volume of agricultural production; meet the interests of all participants in land relations.

Controlling the work of the land market, the state should create programs for economic regulation of agricultural land use.

We believe that the main objectives of land reform should be:

- provision of employment and job creation in rural areas; 
- creation of a new mass class of wealthy hosts- landowners, the so-called «new peasantry», which should become the economic and military support of the Ukrainian State (priority category of landowners);

- economic development, GDP growth, and increased tax revenues;

- protecting the interests of current small landowners by guaranteeing a minimum fair land price.

Summarizing the above, it can be stated that the further development of land reform consists of stimulation of cooperation, improving lease relations and expanding mortgage operations. Provided that elements of a full-fledged land market are formed, this will ensure removing the moratorium and introduce a state-controlled agricultural land market in Ukraine with certain restrictions. The functioning of such market is an important step for the further socio-economic development of Ukraine, including rural areas on an ecological basis.

The use of a mortgage of land will allow agricultural enterprises to increase the volume of received loans, extend the term of long-term lending for significantly lower interest rates and considerably increase the availability of lending.

\section{References}

Atamaniuk, O., Hreshchuk, H. (2017). Organizational and economic mechanism on the sustainable use stimulation of agricultural appointment land. Land management, cadastre and land monitoring. 4. 37-45.

Department of Statistics in Lviv Region. (2020). https://www.lv.ukrstat.gov.ua.

Doing Agribusiness in Ukraine 2020. (2020). http://ucab.ua.

Hreshchuk H. (2019). Efficiency of land management provision of sustainable land use of agriculture. Scientific Papers: Series «Management, Economic Engineering in Agriculture and rural development». 19(3). $275-280$.

Land Code of Ukraine. (2001). https://zakon.rada.gov.ua/laws/show/2768-14\#Text/

Ministry of Agrarian Policy and Food of Ukraine. (2020). http://minagro.gov.ua.

Pasakarnis, G. (2013). Rural development and challenges establishing sustainable land use in Eastern European countries. Land Use Policy. 30(1). 703-710.

Popov, A., Koshkalda, I. Kniaz, O., Trehub, O. (2019). Land fragmentation of agricultural enterprises in the context of administration of land. Economic Annals-XXI. 176(3-4). 80-90.

Shaxson, T. F. (2008). Sustainable Land Management-Challenges, Opportunities and Trade-Offs. By World Bank staff and others. Washington, DC: IBRD and the World Bank (2006), Experimental Agriculture, 44(1), $136-137$.

Shmatkovska, T. O., Dziamulych, M. I., Yakubiv, V. M., Myshko, O. A., Stryzheus, L. V., Yakubiv, R. D. (2020). Economic efficiency of land use by agricultural producers in the system of their non-current assets analysis: a case study of the agricultural sector of Ukraine. Scientific Papers Series "Management, Economic Engineering in Agriculture and Rural Development", 20(3), 543-554.

Sodoma, R., Skhidnytska, H., Shvorak, A., Shmatkovska, T., Zhurakovska, I. (2018). Peculiarities of agrarian receipts as a modern financial tool. Economic annals-XXI. 169(1-2). 46-49. DOI: 10.21003/ea.V169-09.

Stupen, R., Stupen, M, Dudych, H. (2019). The features of the formation and development of agricultural land market in Ukraine. Scientific Papers: Series «Management, Economic Engineering in Agriculture and rural development». 19(3): 543-548.

Tretiak, A., Tretiak, V., Tretiak, N. (2017). Land reform in Ukraine: trends, consequences in the context of quality of life and public safety. Greene D.S. Kherson.

Yakubiv, V., Sodoma R., Hrytsyna, O., Pavlikha, N., Shmatkovska, T., Tsymbaliuk, I., Marcus, O., Brodska, I. (2019). Development of electronic banking: a case study of Ukraine. Entrepreneurship and Sustainability Issues. 7(1). 219-232. DOI: 10.9770/jesi.2019.7.1(17).

Zeeuw, K., \& Salzmann, M. (2011). Cadastral Innovation Driven by Society: Evolution or Revolution. FIG Working Week 2011: Bridging the Gap between Cultures. 